\title{
Mobile Mathematics Learning Application Selection using Fuzzy TOPSIS
}

\author{
Seren Başaran ${ }^{0000-0001-9983-1442, ~} 1$ \\ Near East University, Department of Computer Information \\ Systems \\ Lefkoşa 98010 via: Mersin 10 Turkey, Cyprus
}

\author{
Firass El Homsi ${ }^{2}$ \\ Arab International University \\ Department of Management Information Systems \\ Damascus, Syria
}

\begin{abstract}
Impressive evolution of technology increased the usage frequency of smart mobile phones, and hence abundance in the quantity of available mobile applications has emerged as the vital problem of inventing practical and efficient ways for selecting suitable mobile applications for the desired use. Today, there are almost three million apps only at the Google Play store. Therefore, the need for an automated, effective, and less timeconsuming approach towards suitable mobile application selection to choose the best alternative has gained more significance than ever. Despite the sudden growth in mobile learning applications, there exists a dearth of research in the effective way of selecting a suitable mobile application in that respect particularly in relation to mobile apps for Mathematics. Moreover, using multi-criteria decision-making methods (MCDM) is only recently applied in rare studies for that purpose. This paper focused on ISO/IEC 25010 software quality standards in selecting mobile Mathematics learning applications. Six highly rated applications were evaluated by two experts. This paper aims to apply the fuzzy Technique for Order Preference by Similarity to Ideal Solution (TOPSIS) to retrieve the best alternative among present applications. The results showed an objective and flexible assessment for ranking to eliminate ambiguity in decision-making. Results also identified significant features thus rendering a useful and valuable tool for decisionmakers. The study assists users, teachers/instructors, students in their decision-making processes regarding finding the most suitable application for Mathematics.
\end{abstract}

Keywords-Fuzzy TOPSIS; ISO/IEC 25010 standards; mathematics; mobile applications; multi-criteria decision making

\section{INTRODUCTION}

The number of mobile applications developed each year is growing exponentially. This increase is highly noticeable in the area of digital learning objects [1]. These developments are justifiable by ideas given by [2] which contend that new, better, and effective learning platforms are needed to facilitate learning. It is also clearly seen that developments in mobile learning applications are concurrent with educational developments. In such regard, one can contend that ideas in [3] expressed gratitude to the development of mobile mathematics learning applications. This stems from their contribution towards learning algebra, statistics, geometry, mathematical analysis, and other calculations. The authors of the study in [4] also established that mobile learning applications have made it easy to harness meta-cognitive abilities and represent thoughts in a better way. Researchers in [5] posts that mobile learning applications are essential in dealing with matters that involve a lot of problem-solving and critical thinking. These contributions made by using mobile learning applications are numerous and some are continuing to be discovered with time. This is one of the major reasons why it is important to conduct studies related to the use of mobile learning applications especially in the field of mathematics.

Meanwhile, there exist different ways which can be used to determine the quality of mobile learning applications as well as their contributions towards improving user experience. These standards include ISO-25010, ISO-9126, and FURPS (Functionality, Usability, Reliability, Performance and Supportability). They primarily focus on the software quality aspects of the mobile learning applications [6], [7]. But most of the existing studies that evaluate the quality of mobile learning applications highly focus on technical aspects.

High-quality and improved user experience is not guaranteed by the availability of numerous alternative mobile learning applications for mathematics. The outcome of numerous researches shows that some of the existing mobile learning applications have not contributed much to learning [8], [9]. This is highly true with regards to observations which exhibit that quite a number of mobile learning applications for mathematics have high ratings which do not match their contributions towards improving learning [10].

The study conducted [6] strongly argues that some users prefer not to use mobile Mathematics learning applications (MMLAs). The primary reason is that they are not easy to use. Another reason was given by [3] which contend that several MMLAs involve a lot of manual selection. This is critical because it increases the time users spend before starting to have final access to the application. Matters are worsened by the fact that there is a lot of dissatisfaction surrounding the use of MMLAs. This is attributed to ideas which contend that MMLAs are not much different from traditional mathematics learning methods [6], [9]. That is, they are of low quality and do not contribute much towards improving user satisfaction.

As a result, it can thus be seen that there is a huge need to develop and select high-quality, user-friendly, and userenhancing experience MMLAs. Another challenge posed is that this topic is a new and emerging one in the study of MMLAs. Hence, more work is needed to study how mathematics learning quality and user experience can be improved notably by using multi-criteria decision-making methods. These techniques can guarantee a high level of 
success in quality evaluation [11]. For this purpose, this study thus seeks to use a fuzzy TOPSIS method to select highquality and user-enhancing experiences of mobile learning applications for mathematics.

The main objective of this study is to use the fuzzy TOPSIS approach to select high-quality and user-enhancing experiences of mobile learning applications for mathematics. This study also seeks to identify problems that are undermining the use of MMLAs and offer solutions to deal with such challenges.

The study aids in enhancing the use and effectiveness of MMLAs. The outcomes of the study are believed to improve learning across all platforms by addressing significant challenges affecting the use of MMLAs. This study also provides standards in relation to ISO practices upon which the quality and usability of MMLAs can be determined. Moreover, it plays an important role to the study of mobile applications through the use of Fuzzy TOPSIS.

That is, it contributes towards improving existing empirical frameworks on Fuzzy TOPSIS. This technique is otherwise known as the Fuzzy TOPSIS approach and came into existence as a result of efforts to provide a framework for choosing the ideal alternative [12]. The decision is made based on the most and closest distance between the negative ideal solution and the positive ideal solution [13].

The rest of the paper is organized as follows: The literature review is discussed in Section II. The decision-making approach for evaluation is described in Section III with the introduction of sample mobile learning applications. The fourth section is dedicated to the findings and the subsequent discussion. The conclusion is discussed in Section V.

\section{RELATED WORK}

There are circumstances that require a lot of decisions to be made simultaneously. These decisions are most times conflicting and require an objective criterion to help make the best and relevant decision. This leads to Multi-Criteria Decision Making (MCDM). MCDM primarily includes a combination of expert views and the use of historical data to make decisions [14]. It thus quantifies subjective judgments and implies that the best MLAM must be part of MCDM. MCDM is composed of a number of approaches which include: VIKOR, TOPSIS, ELECTRE, PROMOTHEE, and Analytic Hierarchy Process (AHP). The key to making the right decision is to examine the weight of the choices which vary in relation to their relative values. Hence, the challenges of subjectivity and imprecision are bound to be encountered in any MCDM activity. MCDM applies in a lot of circumstances and areas. In Mathematics, the MCDM can be related to quality, usability, costs, convenience, reliability, accuracy and dependability, accessibility, etc. For students to highly benefit from the use of MMLAs, these MCDM aspects are essential and must be prioritized.

The growth and advancement in technological accessibility and digital globalization over the past two decades have greatly impacted learning. This has opened more opportunities for learning by removing physical limitations. Hence, learning is becoming increasingly mobile [15]. In general terms, a mobile application is any software application that permits the user to undertake certain tasks through the use of a mobile (handheld or wireless) device such as tablets, smartphones. This promotes accessibility at any point in time in respect to the usual assigned position or location.

Using MLAs on handheld and wireless devices help promote collaboration and individualization of the learning process as hinted by [16]. This, therefore, means that students can learn at their own convenience and pace. The importance of this is heightened by the fact that learning is not hampered when students do not have physical access to classroom materials or desktop computers.

According to [17], mobile learning (m-learning) and electronic learning (e-learning) are greatly influenced by the existence of mobile learning devices (MLDs). Hence the absence of MLDs can hamper both m-learning and e-learning. This is further seen by insights provided by [18]. These insights established that the lack of MLDs hindered the growth, development, and use of mobile.

WELCOME (Wireless E-Learning and Communication Environment) was used by [19] as part of m-learning strategies to examine students' experience and performance. The results showed that m-learning is a desirable and essential feature for contemporary education. It further established that m-learning enhances the experience and effectiveness of students. This was further improved with the integration of WAP (Wireless Access Protocols).

Other researchers such as in [20] have focused on the integration of m-learning with SMS technology in universities. The study involved the use of whiteboards. In this study, students asked questions, took part in classroom discussions, and provided feedback. This feature greatly showed the need for proper categorization of students into the entire learning process by time, receiver, sender, etc. Such can also be extended to the examination of MMLAs. The most interesting development was by [17] and it involved the development of a tutoring system that allows users to access it using handheld and wireless devices. Such a system captured student performance, records and included an assessment platform. In addition, this has been a solid platform upon which MMLAs and other learning applications have been developed.

From all these insights, deductions can be made that mobile learning is an innovative approach to learning. This inference stems from the numerous benefits that users or learners are bound to get from using them. Mobile learning applications can thus be said to enhance convenience, accessibility, speed, interaction, collaboration activities in learning.

However, this relies on quite a several factors such as the availability of internet access and mobile devices. Also, researchers in [20] established that lack of quality can hinder the use of MLAs. Researchers in [19] noted the need to enhance user satisfaction as another key aspect to enhancing the use of MLAs. These issues are the driving motivation for this study to identify the high quality MMLAs using the Fuzzy TOPSIS approach. 
The integration of MLAs in mathematics is a great innovative move that works towards improving learners' knowledge and understanding of mathematical aspects. Researcher in [21] posits that the use of MMLAs enhances learners' chances of being successful or performing better in mathematics. As such, the whole process of learning mathematics can be casual and unconstrained as users can use any MLDs such as cell phones and tablets.

It was highlighted that MMLAs tend to deal with arithmetic problems faced by learners [3]. This is because MMLAs are designed to suit any individual irrespective of his or her mathematical abilities and most of the modules provided start from elementary aspects or basics of any mathematics subject. Hence, MMLAs can be considered to deal with deeper mathematical issues such as numerical programming, critical thinking, geometrical constriction, charts representation, etc.

Authors in [22] used Maths4Mobile to look at the use and importance of arranged and social learning angles in learning mathematics. Their results provided support of the additional benefits obtained from using MMLAs over traditional learning methods. The cited reasons pointed towards increased coordination and engagement amongst the students.

A study that examined the situational learning environment involved the use of Nokia mobile phones to learn Mathematics [23]. Findings showed that the use of mobile phones greatly encouraged students to participate in learning mathematics. In addition, more students were observed to have greatly improved in their academic performance with regards to mathematics. Recommendations were made that the use of mobile phones encourage unaided learning and hence using MMLAs can play the same role too.

The use of MMLAs attracted and continues to attract the attention of major and reputable bodies which are in support of their use. For instance, the U.S. National Council of Teachers of Mathematics in 2008 encouraged educational institutions to allow students' access to MLAs. Such developments were said to foster speed, creativity, and innovation in learning ${ }^{1}$.

The authors of the study in [24] gave different arguments concerning the use of MMLAs citing that they can also obstruct the learning process. This is considerably true as students can shift focus towards non-educational activities on mobile applications [25]. Despite the occurrence of these problems, it is still being advocated that MMLAs play an important role in mathematics [26]. Hence, we can expect such a notion to play an important role in learning mathematics as innovative developments continue to take place in the foreseeable future.

It is worthy to note that user satisfaction and quality enhancement are also important aspects to look at when examining both the importance and drawbacks of using MLAs. For instance, the use of MLAs does not guarantee user satisfaction. Such can be seen in reviews that are given by users who sometimes complain of using the MLAs. Hence, the

${ }^{1}$ (NCTM), N. C. (2008). Retrieved from www.nctm.org number of users using the MLAs is often a good indicator of determining if such MLA is good or bad and if it has problems or not. Ratings are also another strategy that can be used to examine the existence of drawbacks. That is, higher ratings such as 4.5 and 5 or possibly more offer an indication that the MLA has little or no problems affecting it.

Though MMLAs learning applications have a lot of benefits that users can obtain from using them, they are still prone to suffer or pose numerous drawbacks. For instance, researchers in [6] established that most MLAs always fail to live up to expectations.

The reason is that they fail to serve the intended purpose. That is, not all MMLAs offer the desired mathematics learning materials and some materials are relatively few and inaccessible.

Meanwhile, applications are themselves part of the full composition of what is termed software and hence any problem that is surrounded by the use of software can affect the use of MLAs. For instance, software crush problems can make MLAs inaccessible and this can happen most when users are in great need of the application. Most of them require constant updates and may not work with certain mobile devices. For instance, certain MLAs are restricted to IOS while other work only on Android and Windows operating systems.

From all these drawbacks, the development of high quality and user enhancing MLAs has to consider all these challenges. As a result, an assumption can be made that mobile applications that have higher ratings such as 4.5 and 5 or possibly more and a high number of users, offer an indication that the MLA has little or no problems affecting it. However, multiple MLAs might have high ratings despite their flaws. To minimize this ambiguity, multi-criteria decision-making methods were offered.

Researchers examined the use of fuzzy TOPSIS and FAHP in addressing user satisfaction and quality issues involved in using MMLAs [6]. The study focused on 5 MMLAs with higher user ratings of 5 available on Google Play Store. The findings revealed that the best and less time-consuming MMLAs can be selected by using Fuzzy TOPSIS and FAHP.

Fuzzy TOPSIS approach is better when used to rank the decisions while the FAHP works better in assigning weights [27]. This entails that the Fuzzy TOPSIS approach works more efficiently in ranking the best MMLAs.

The study also used the Fuzzy TOPSIS and FAHP to analyze the food industry's product life cycles in Iran [28]. That study used MCDM methods to demonstrate that the best cycle can be obtained with little or no effort. The FAHP was noted to offer the best decision without using a lot of effort. But the given recommendations pointed out that the Fuzzy TOPSIS methods can offer better results when used in a different context such as mobile apps.

Some studies advocate the combined use of Fuzzy TOPSIS and FAHP methods [29]. But it was highlighted that this is also conditional on the need to either assign weights or ultimately rank the judgments. With little focus being given on 
the use of the Fuzzy TOPSIS approach to rank MMLAs, this study, therefore, deems the use of the Fuzzy TOPSIS approach is best suitable to developing a web application for ranking MMLAs.

Researchers in [30] used the fuzzy TOPSIS to assess 34 systems to locate the most adequate business intelligence for enterprise systems. This involved the computation of evaluation scores and the assigning of ranks to the systems. This approach was justified in its use citing that it allows selection, assessment, and purchasing. The findings were in line with this proposition and considerations can be made that the same can be made with regards to MMLAs, whereas the focus was primarily on quality and user-enhancing aspects of the MMLAs.

A study analyzed the use of the Fuzzy TOPSIS and AHP approaches to assign weights and rank alternatives respectively [31]. The results showed that both approaches are viable in dealing with MCDM issues. Hence, the same expectations can be individually made with regards to the Fuzzy TOPSIS approach.

MMLAs are an innovative approach and their integration in education offers a widespread number of benefits. Such benefits tend to be more when weighed against traditional learning methods. One can thus contend that aspects relating to convenience, easy access, mobility and time are major beneficial attributes of using MMLAs. However, there are also a series of problems that can undermine the use of MMLAs. These problems relate to the purpose over actual results, quality, reliability, user satisfaction, software, costs, and accessibility (internet access) aspects of MMLAs. Any challenge pertaining to these aspects can hinder the use of MMLAs. The notable idea is that the use of the Fuzzy TOPSIS which is deemed to be an optimal, viable solution to select high-quality MLAs.

In this study, the application of the Fuzzy TOPSIS approach can be based on determining the best MLAM which is either reliable, fast, easy to use, of high quality, cheaper, covers a lot of topics, etc. However, all these elements can be embodied under user experience, and hence choosing the best and high-quality MLAM that enhances user experience.

Well-known research issues have been shown to support the need for increased development of quality and user satisfaction models. These researches have also revealed that existing MLAs have not greatly impacted learning. Numerous observations which expose a mismatch between MLAMs user ratings and their contributions to improving the learning experience have further reinforced this. The quality of MLAMs has also been confirmed to be below par in most scenarios. There is a need for quality standards for the proper evaluation of mobile Mathematics learning applications.

For this purpose, ISO/IEC 25010 was established in 2011. It is a product quality standard that provides a platform where developers can evaluate and choose the software properties they wish to focus on. ISO 25010 considers the best software as that which can meet at least eight of the stated quality features.
- Functional suitability: This ensures that the laid down criteria are always met by the developed MMLAs. Subcharacteristics such as functional completeness, correctness, and appropriateness must also be met. Hence, for the MMLAs to function properly they must meet all the laid down objectives. The objectives and tasks include assigning the needed results in the proper way and with high precision. This ensures that objectives are met and tasks completed.

To extent which a product or system offers the right functionality is satisfied by some given sub-characteristics under certain conditions. These sub-characteristics must show the following:

- Functional completeness: All user objectives and specified tasks must have a degree of functionality to be satisfied. This is called functional completeness.

- Functional correctness: The product or system must also provide the right results at a high degree of correctness.

- Functional appropriateness: Specified tasks and objectives must be facilitated and accomplished to a high degree.

- Performance efficiency: The developed software or application is required to work efficiently at a rate that does not involve the consumption of many resources. This can be achieved by using a few and limited kinds of resources when functioning. To be efficient, it must provide a high degree of result at a minimum time that is, it should not take a long time to complete the required task. Researcher in [32] has shown that an application's efficiency is shown by its ability to meet required tasks at its maximum limits. This can also be gauged by considering the performance in comparison to the number of resources under the given conditions. Performance efficiency includes:

- Time behavior: While executing its task to comply requirements, a system time behavior is measured by the extent to which the reaction and processing are put in it.

- Resource utilization: While performing, it is measured by the extent to which amounts and types of resources are put into it.

- Capacity: It refers to extent which a system's maximum limits align with the given requirements.

- Compatibility: It is the degree which a system can deliver information while performing its required functions under shared conditions with other systems. This feature includes:

- Co-existence: Sharing a same environment and resources with other products can cause harm to a product and prevent it from performing as intended. The degree to which it can prevent this is called coexistence. 
- Interoperability: The use and exchange of information between two or more systems are possible. The degree to which they can do this is called interoperability.

- Usability: This refers to how well a system may be utilized by specific people to achieve specific objectives. To do this it must be effective, efficient, and satisfy the specified task. The usability includes:

- Appropriateness recognizability: Users must see if their system meets their needs. Appropriateness recognizability is the measure of how well this can be performed.

- Learnability: This refers to the extent to which a system may be used by a specific group of people. It signifies that the user uses the system to attain certain learning objectives. It provides effectiveness, efficiency, riskfree operation, and satisfaction in a certain usage environment.

- Operability: This refers to how well a system is designed to be simple to use, operate, and navigate.

- User error protection: This refers to how well a product or system protects users from making mistakes.

- User interface aesthetics: This is the extent to which a user interface allows for satisfying and enjoyable engagement.

- Accessibility: This refers to a product's or system's ability to be utilized by people with a wide range of features and abilities. It assists users in achieving a certain goal in a specific setting.

- Reliability: A system is considered reliable if it performs specified functions to a certain degree under given conditions for a specified period of time. Reliability includes:

- Maturity: This is the degree to which a system satisfies reliability requirements under regular operation.

- Availability: This is the degree to which a system is operational and available for a certain task when it is required.

- Fault tolerance: This is the degree to which a system can work even if it has defects in its hardware or software.

- Recoverability: In the event of an interruption or failure, this is the degree to which a system recovers the data directly damaged. It also brings the system back to its original state.

- Security: A system's information and data must be properly protected in order for other systems to have the right level of data access for their types and levels of authorization. This is called security. Security includes:

- Confidentiality: This is the degree to which a system's data is exclusively available to those who have been granted access.
- Integrity: Unauthorized users should not be able to access or modify a system's programs or data, thus it must be able to identify and prohibit them.

- Non-repudiation: This is the degree to which a system's actions or occurrences may be verified to have occurred. This eliminates the possibility of future repudiation for the events or actions.

- Accountability: This is the degree to which a system's actions may be traced back to another entity.

- Authenticity: This is the degree to which a subject's or resource's identification may be proven to be the one asserted.

- Maintainability: This shows how effective and efficient a system is. This is done in order to improve, fix, or adapt it to diverse environmental and other constraints. Maintainability includes:

- Modularity: This indicates how many separate components make up a system. When one component is changed, the effect on the other components is modest.

- Reusability: This is the extent to which an asset can be used in a variety of different assets. It can also be used to construct or create new items.

- Analyzability: There are times when one or more pieces of a system or product need to be changed. This is done to figure out what's wrong with the parts or what's causing them to fail. It can also be used to locate pieces that need to be fixed or modified. Analyzability refers to the degree of efficacy and efficiency with which something can be accomplished.

- Modifiability: The capacity of a system to be modified correctly without adding errors or degrading its existing quality is referred to as modifiability.

- Testability: This is the effectiveness and efficiency of a system that is used to set test criteria. It also refers to the extent to which tests can be performed to see if the requirements have been met.

- Portability: This refers to how easily a system, product, or component may be moved from one piece of hardware or software to another. It also demonstrates how quickly it may be moved from one operational or application setting to another. Portability includes:

- Adaptability: This refers to how well a system can be converted to new or changed hardware, software, or other operational or usage settings successfully and efficiently.

- Installability: This is the level of efficacy and efficiency with which a system can be successfully installed and/or uninstalled in a given environment.

- Replaceability: This is the degree to which one software can be replaced by another for the same purpose in the same environment or setting. 
- Flexibility: It is the ability of the software to adapt itself easily to different user/system related requirements.

- Effectiveness: It is defined as the degree to which software performs tasks properly.

As the reviewed relevant studies have implied that despite the rapid expansion of mobile learning applications, there is a paucity of research on the most effective methods for picking a good mobile application, particularly for mobile apps for mathematics. Furthermore, only a few researches have used multi-criteria decision-making methods (MCDM) for that aim. Therefore this study aims to fill this gap in the literature.

\section{METHODOLOGY}

\section{A. Triangular Fuzzy Numbers $(T F N)$}

The transformation process of fuzzy member functions is based on the assumption or rule that an equal membership function ranging from $0.25-0.30$ can be assigned to each rank (Torfi, Farahani \& Rezapour, 2010). For instance, a low triangular fuzzy member of 0.000 can be assigned to a very low fuzzy variable (see Fig. 1) Table I shows the linguistic variables used for the fuzzification of the criteria. Table II shows the linguistic variables used for the fuzzification of weights.

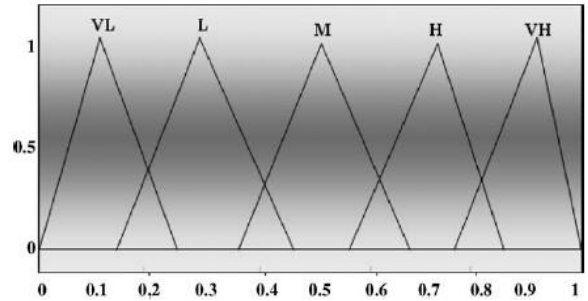

Fig. 1. Fuzzy Triangular Membership Functions.

TABLE I. TRANSFORMATION FOR FUZZY MEMBERSHIP FUNCTIONS [31]

\begin{tabular}{|l|l|l|}
\hline Rank & Sub-criteria grade & Membership function \\
\hline Very low (VL) & 1 & $(0.00,0.10,0.25)$ \\
\hline Low $(\mathrm{L})$ & 2 & $(0.15,0.30,0.45)$ \\
\hline Medium $(\mathrm{M})$ & 3 & $(0.35,0.50,0.65)$ \\
\hline High $(\mathrm{H})$ & 4 & $(0.55,0.70,0.85)$ \\
\hline Very high $(\mathrm{VH})$ & 5 & $(0.75,0.90,1.00$ \\
\hline
\end{tabular}

TABLE II. LINGUISTIC VARIABLES FOR THE WEIGHT

\begin{tabular}{|l|l|l|}
\hline Rank & Rating & Membership function \\
\hline Unnecessary (U) & 1 & $(0,0.1,0.25)$ \\
\hline Not Important (NI) & 2 & $(0.15,0.30,0.45)$ \\
\hline Important (I) & 3 & $(0.35,0.5,0.65)$ \\
\hline Very Important (VI) & 4 & $(0.55,0.7,0.85)$ \\
\hline Essential (E) & 5 & $(0.75,0.9,1.0)$ \\
\hline
\end{tabular}

\section{B. Mobile Mathematics Learning Applications as Alternatives}

Table III shows a total of six MMLAs with user ratings of at least 4.2 and 100000 downloads were selected from Google Play Store and Apple Store. Thus, these six MMLAs constitute a sample of MMLAs that were used in this study to create a platform upon which the best mobile mathematics applications in terms of high-quality and user enhancing experience can be selected.

TABLE III. ALTERNATIVES

\begin{tabular}{|l|l|l|l|l|}
\hline $\begin{array}{l}\text { Math } \\
\text { application }\end{array}$ & \multicolumn{2}{|l|}{ Google Store } & \multicolumn{2}{l|}{ Apple Store } \\
\hline & $\begin{array}{l}\text { User } \\
\text { ratings }\end{array}$ & $\begin{array}{l}\text { Downloads in } \\
\mathbf{2 0 1 8}\end{array}$ & $\begin{array}{l}\text { User } \\
\text { ratings }\end{array}$ & $\begin{array}{l}\text { Downloads in } \\
\mathbf{2 0 1 8}\end{array}$ \\
\hline $\begin{array}{l}\text { yHomework } \\
\text { Math Solver }\end{array}$ & 4.2 & $1000000+$ & 4.6 & $3000000+$ \\
\hline Cymath & 4.5 & $100000+$ & 4.3 & $100000+$ \\
\hline Malmath & 4.6 & $500000+$ & N/A & N/A \\
\hline Math 42 & 4.6 & $500000+$ & 4.5 & $3400000+$ \\
\hline MathPapa & 4.7 & $500000+$ & 4.7 & $500000+$ \\
\hline PhotoMath & 4.7 & $50000000+$ & 4.8 & $100000000+$ \\
\hline
\end{tabular}

1) yHomework - math solver: Math Solver in Fig. 2 specifically focues on dealing with algebra issues but also incorporates mathematicals topics involving the use of graphs, solving inequalities and other types of equations. The applications simply requires users to enter an equation and it automatically computes the answer for the user.

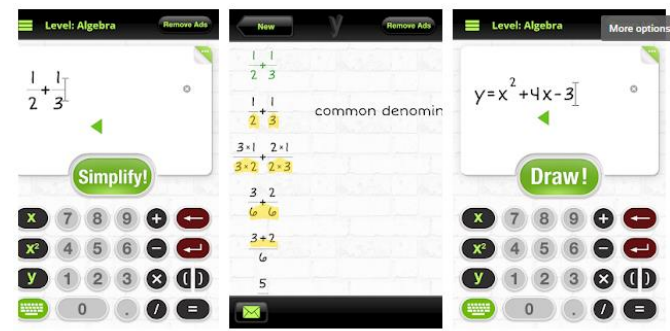

Fig. 2. Screenshot of yHomework - Math Solver.

2) Cymath: Cymath depicted in Fig. 3 solves math problems such as algebra (eg. quadratic equations, complex numbvers, exponents, logarityhms factoring etc.) and calculus (eg. trigonometric substitution, integration, u-substitution, chain rule etc.) using the same mathematical engines. As such, it simply allows users to enter the mathematical problem and then automatically computes the answer for them.

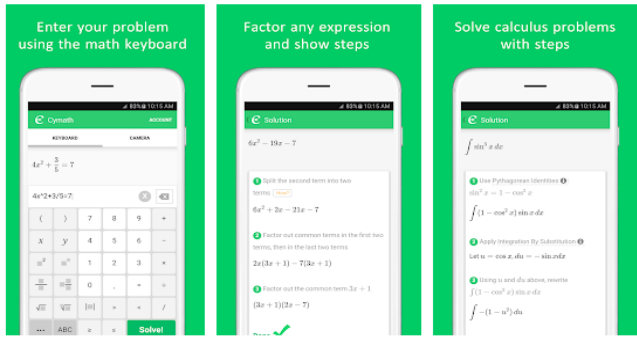

Fig. 3. Screenshot of CyMath. 
3) Malmath: MalMath shown in Fig. 4 is used to solve mathematical problems with graphical interface and instructions. It is freely available working online and offline together. It helps in dealing with topics involving the solving of algebra, integrals, equations, derivatives, trigonometry, logarithms, limits, etc. It provides solving process as well and inteded for high school and university students and instructors/teachers.
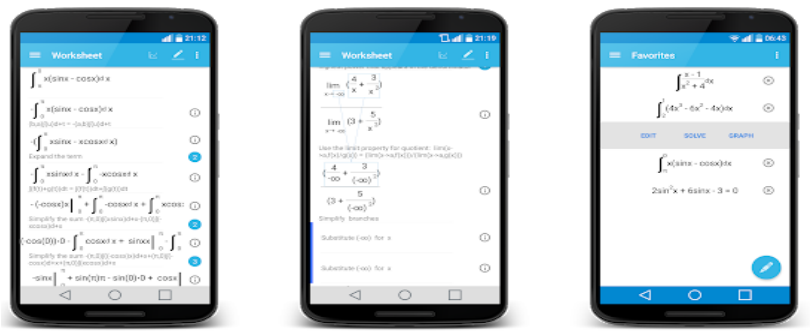

Fig. 4. Screenshot of MalMath.

4) Math42: Math42 given in Fig. 5 provides innovative, step by step checking process guide to solving problems and it also includes test center. It also includes features such as autocomplete formula entry recommendations during problem solving.

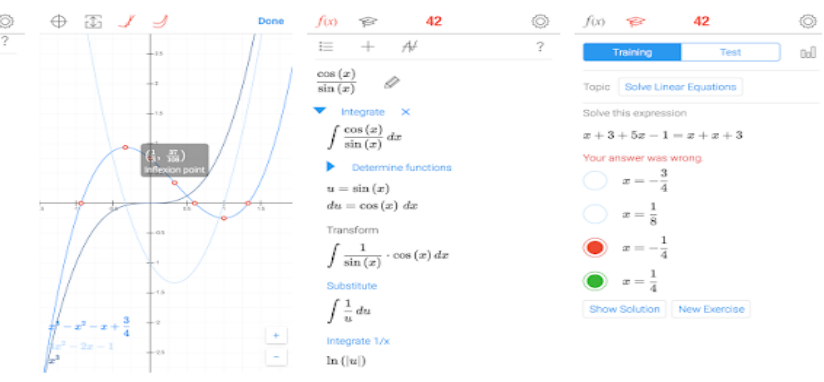

Fig. 5. Screenshot of Math42.

5) MathPapa: MathPapa depicted in Fig. 6 provides aid in solving particularly linear equations and quadratic equations and inequalities, graphs.
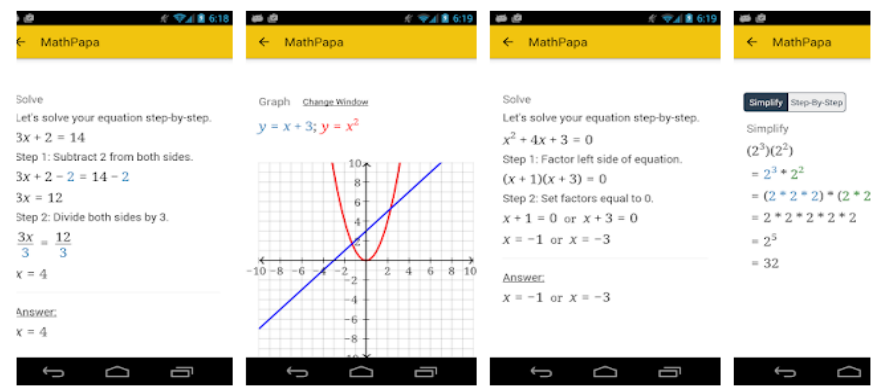

Fig. 6. Screenshot of MathPapa.

6) PhotoMath: PhotoMath shown in Fig. 7 provides guide for solving mathematical problems. It includes monitoring for assignments and exams. Photomath is freely available and works online. It has scanned text and handwriting text recognition feature.

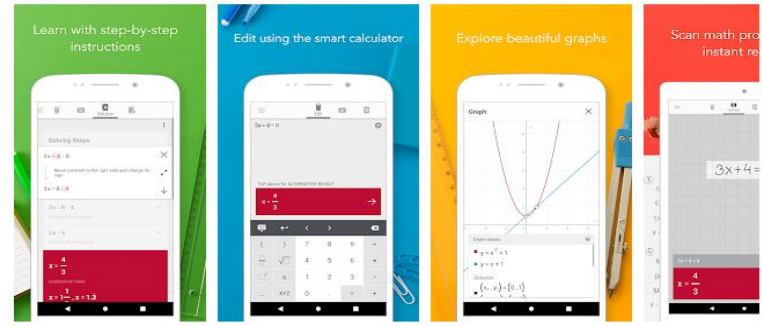

Fig. 7. Screenshot of PhotoMath.

\section{Fuzzy Technique for Order Preference by Similarity to Ideal Solution (TOPSIS) Method}

The steps taking in the research include:

Step 1: A survey was set and given to the decision makers. The decision makers then evaluated the questions for six alternative set for the selected criteria.

Let $\mathrm{m}$ be number of alternatives $\{\mathrm{A} 1, \mathrm{~A} 2 \ldots, \mathrm{Am}\}(\mathrm{m} \geq 2)$

For this research, $\mathrm{m}=6$.

Let $\mathrm{n}$ be the Number of Criteria $\{\mathrm{C} 1, \mathrm{C} 2 \ldots \mathrm{Cn}\}(\mathrm{n} \geq 2)$

For this research, $\mathrm{n}=12$.

Let $w$ be the vector of Criteria Weights $(0 \leq \mathrm{w} \leq 1)$, while $\Sigma_{1}^{n} w_{i}=1$.

Let DM be the number of Decision Makers that assess the alternatives (A) and all the Criteria (C) while \{DM1, DM2, $\ldots, \mathrm{DMK}\}(\mathrm{K} \geq 2)$

For the research, $\mathrm{DM}=2$.

Step 2: The results from Step 1 were imputed into the web based software for the matrix which thereafter, went through the process of calculating the normalized fuzzy decision.

The Decision Making Matrix

$$
\begin{aligned}
& \mathrm{X}^{\mathrm{k}}=\begin{array}{c}
A_{1} \\
A_{2} \\
\vdots \\
A_{m}
\end{array}\left[\begin{array}{cccc}
x_{11}^{k} & x_{12}^{k} & \cdots & x_{1 n}^{k} \\
x_{21}^{k} & x_{22}^{k} & \cdots & x_{2 n}^{k} \\
\vdots & \vdots & \ddots & \vdots \\
x_{m 1}^{k} & x_{m 2}^{k} & \cdots & x_{m n}^{k}
\end{array}\right] \\
& \begin{array}{lllll}
C_{1} & C_{2} & \ldots & C_{n}
\end{array}
\end{aligned}
$$

The normalized fuzzy decision matrix

$$
\begin{gathered}
\mathrm{Y}^{\mathrm{k}}=\begin{array}{c}
A_{1} \\
A_{2} \\
\vdots \\
A_{m}
\end{array}\left[\begin{array}{cccc}
x_{11}^{k} & x_{12}^{k} & \cdots & x_{1 n}^{k} \\
x_{21}^{k} & x_{22}^{k} & \cdots & x_{2 n}^{k} \\
\vdots & \vdots & \ddots & \vdots \\
x_{m 1}^{k} & x_{m 2}^{k} & \cdots & x_{m n}^{k}
\end{array}\right] \\
C_{1} \quad C_{2} \quad \cdots \quad C_{n}
\end{gathered}
$$

Where

$$
y_{i j}^{k}=\left\{\begin{array}{l}
\left(\frac{a_{x_{i j}^{k}}}{\max _{i} d_{x_{i j}^{k}}}, \frac{{ }^{b} x_{i j}^{k}}{\max _{i} d_{x_{i j}^{k}}}, \frac{{ }^{c} x_{i j}^{k}}{\max _{i} d_{x_{i j}^{k}}}\right) \text { if } j \in B \\
\left(\frac{\min _{i} a_{x_{i j}^{k}}}{a_{x_{i j}^{k}}}, \frac{\min _{i} a_{x_{i j}^{k}}}{{ }^{b_{x_{i j}^{k}}}}, \frac{\min _{i} a_{x_{i j}^{k}}}{{ }^{c} x_{i j}^{k}}\right) \text { if } j \in C
\end{array}\right.
$$


Step 3: Thereafter, the result was imputed into another matrix to obtain the weighted normalized fuzzy decision.

The weighted normalized fuzzy decision matrix

$$
\mathrm{v}^{\mathrm{k}}=\begin{gathered}
A_{1} \\
A_{2} \\
\vdots \\
A_{m}
\end{gathered}\left[\begin{array}{cccc}
v_{11}^{k} & v_{12}^{k} & \cdots & v_{1 n}^{k} \\
v_{21}^{k} & v_{22}^{k} & \cdots & v_{2 n}^{k} \\
\vdots & \vdots & \ddots & \vdots \\
v_{m 1}^{k} & v_{m 2}^{k} & \cdots & v_{m n}^{k}
\end{array}\right]
$$

$$
\begin{array}{llll}
C_{1} & C_{2} & \ldots & C_{n}
\end{array}
$$

Where $v_{i j}^{k}=w_{j} y_{i j}^{k}=\left(w_{j} a_{i j}^{k}, w_{j} b_{i j}^{k}, w_{j} c_{i j}^{k}\right)$

The matrices $v^{k}$ form the basis of the $\mathrm{f}$ weighted normalized fuzzy decision matrices for each alternative $A_{i}$

Step 4: The next step was to determine the positive idea solution, $A^{+}$and the negative idea solution, $A^{-}$using the following equations:

The positive ideal solution $A^{+}$

$$
\begin{aligned}
& \text { Where } A^{+}=\begin{array}{c}
D M_{1} \\
D M_{2} \\
\vdots \\
D M_{m}
\end{array}\left[\begin{array}{cccc}
v_{1}^{1+} & v_{2}^{1+} & \cdots & v_{n}^{1+} \\
v_{1}^{2+} & v_{2}^{2+} & \cdots & v_{n}^{2+} \\
\vdots & \vdots & \ddots & \vdots \\
v_{1}^{k+} & v_{2}^{k+} & \cdots & v_{n}^{k+}
\end{array}\right] \\
& \begin{array}{llll}
C_{1} & C_{2} & \ldots & C_{n}
\end{array} \\
& \text { While } v_{j}^{k+}=\max _{i} v_{i j}^{k}
\end{aligned}
$$

The negative ideal solution $A^{-}$

$$
\text { Where } A^{-}=\begin{gathered}
D M_{1} \\
D M_{2} \\
\vdots \\
D M_{m}
\end{gathered}\left[\begin{array}{cccc}
v_{1}^{1-} & v_{2}^{1-} & \cdots & v_{n}^{1-} \\
v_{1}^{2-} & v_{2}^{2-} & \cdots & v_{n}^{2-} \\
\vdots & \vdots & \ddots & \vdots \\
v_{1}^{k-} & v_{2}^{k-} & \cdots & v_{n}^{k-}
\end{array}\right]
$$

$C_{1} \quad C_{2} \quad \ldots \quad C_{n}$

While $v_{j}^{k-}=\min _{i} v_{i j}^{k}$

Step 5: Finally, the system calculated the relative ideal situation of each alternatives. Then it ranked the alternatives accordingly starting from the closest to the ideal situation. Then the results were obtained.

The distances of each alternative $A_{i}$ represented by matrix $W_{i}$ from positive ideal solution (PIS);

$d_{i}^{+}=\Sigma_{1}^{k} \Sigma_{1}^{n} d\left(v_{i j}^{k} v_{j}^{k+}\right)$

The distances of each alternative $A_{i}$ represented by matrix $W_{i}$ from negative ideal solution (NIS);

$d_{i}^{-}=\Sigma_{1}^{k} \Sigma_{1}^{n} d\left(v_{i j}^{k} v_{j}^{k-}\right)$

Using these distances, the relative closeness coefficients $R C_{i}$ to PIS

Where $R C_{i}=\frac{d_{i}^{-}}{d_{i}^{-}+d_{i}^{+}}$

According to the descending values of $R C_{i}$, all alternatives $A_{i}$ are rank ordered and the best one is selected.

\section{Evaluation Criteria Framework and Ranking}

The MCDM evaluation criteria were based upon the two aspects that were adopted from ISO/IEC 25010. The criteria are; Functional completeness $\left(\mathrm{C}_{1}\right)$, Functional correctness $\left(\mathrm{C}_{2}\right)$, Functional appropriateness $\left(\mathrm{C}_{3}\right)$, Resource utilization $\left(\mathrm{C}_{4}\right)$, Time behavior $\left(\mathrm{C}_{5}\right)$, Appropriateness recognizability $\left(\mathrm{C}_{6}\right)$, Learnability $\left(\mathrm{C}_{7}\right)$. Confidentiality $\left(\mathrm{C}_{8}\right)$, Effectiveness $\left(\mathrm{C}_{9}\right)$, Efficiency $\left(\mathrm{C}_{10}\right)$, Flexibility $\left(\mathrm{C}_{11}\right)$, Satisfaction in Usefulness $\left(\mathrm{C}_{12}\right)$. The alternatives are; yHomework Math Solver $\left(\mathrm{A}_{1}\right)$,Cymath $\left(\mathrm{A}_{2}\right)$, Malmath $\left(\mathrm{A}_{3}\right)$, Math 42( $\left.\mathrm{A}_{4}\right)$, MathPapa $\left(\mathrm{A}_{5}\right)$, PhotoMath $\left(\mathrm{A}_{6}\right)$.

Two decision-makers were involved in the evaluation process of the alternatives. The first expert $\left(\mathrm{DM}_{1}\right)$ has a background in Educational technology. The second expert has a background in computer information systems $\left(\mathrm{DM}_{2}\right)$. The rationale for involving the limited number of decision-makers lies in the challenge of locating decision-makers with the proper area of expertise who not only have knowledge and experience on software quality standards but also have an adequate background on how to evaluate the software.

\section{RESUlts}

The ranking process starts with the two decision makers evaluate six alternatives by using the twelve criteria derived from ISO/IEC 25010 software quality standard metrics. The linguistic scale given in Table I was used to evaluate criteria by the experts. The two decision matrices of the evaluated alternatives were given in Table IV and Table V respectively. Later, the evaluation of the decision makers was converted into fuzzy scales. Fuzzy decision matrices for decision maker 1 and decision maker 2 were shown in Table VI and Table VII, respectively. By using the linguistic weights given in Table II, the weighted decision matrix was calculated and is specified in Table VIII. The weighted decision matrix is then normalized and ideal solutions were calculated which were given in Table IX. The normalized positive and negative ideal solution matrices are shown in Table $X$ and Table XI respectively. The Table XII shows the closeness to the ideal solutions from highest to lowest and the final ranking of the alternatives. The results revealed that PhotoMath $\left(\mathrm{A}_{6}\right)>$ Malmath $\left(\mathrm{A}_{3}\right)>$ Math $42\left(\mathrm{~A}_{4}\right)>\operatorname{Cymath}\left(\mathrm{A}_{2}\right)>\operatorname{MathPapa}\left(\mathrm{A}_{5}\right)>$ yHomework Math Solver $\left(\mathrm{A}_{1}\right)$ where PhotoMath has the highest rank whereas yHomework Math Solver has the lowest rank in terms of selected criteria according to fuzzy TOPSIS ranking procedure.

To authors' knowledge, studies that employ MCDM techniques to evaluate the quality of mobile apps particularly for Mathematics are quite limited. This constitutes the essential driving motivation to conduct such research. The study has some superior features as compared to the earlier studies in the literature. The authors of an earlier study in [6] only considered five alternatives and merely one decision maker whereas this research included six alternatives and two decision makers. Another study applied ELECTRE I to five alternatives with only one decision maker [11] whereas the number of decision makers in this study is two and the number of alternatives are more. It was inferred that fuzzy TOPSIS method can be quite effortlessly employed. The fuzzy TOPSIS procedure is a popular technique used in other studies where 
researchers used fuzzy TOPSIS methods to evaluate four general learning applications with 175 students using 25 criteria [33]. Earlier relevant studies have integrated FAHP and conventional TOPSIS techniques [6] or used TOPSIS to evaluate 6 language learning apps with six experts and 17 criteria [34], [35] whereas in the absence of precise performance ratings fuzzy TOPSIS is the prominent technique over conventional TOPSIS which justifies the use of fuzzy TOPSIS in this study.

TABLE IV. DM DECISION MATRIX

\begin{tabular}{|l|l|l|l|l|l|l|l|l|l|l|l|l|l|}
\hline $\mathbf{D M}_{\mathbf{1}}$ & $\mathbf{C}_{\mathbf{1}}$ & $\mathbf{C}_{\mathbf{2}}$ & $\mathbf{C}_{\mathbf{3}}$ & $\mathbf{C}_{\mathbf{4}}$ & $\mathbf{C}_{\mathbf{5}}$ & $\mathbf{C}_{\mathbf{6}}$ & $\mathbf{C}_{\mathbf{7}}$ & $\mathbf{C}_{\mathbf{8}}$ & $\mathbf{C}_{\mathbf{9}}$ & $\mathbf{C}_{\mathbf{1 0}}$ & $\mathbf{C}_{\mathbf{1 1}}$ & $\mathbf{C}_{\mathbf{1 2}}$ \\
\hline $\mathbf{A}_{\mathbf{1}}$ & $\mathrm{H}$ & $\mathrm{H}$ & $\mathrm{L}$ & $\mathrm{VH}$ & $\mathrm{M}$ & $\mathrm{L}$ & $\mathrm{VH}$ & $\mathrm{L}$ & $\mathrm{H}$ & $\mathrm{M}$ & $\mathrm{H}$ & $\mathrm{VH}$ \\
\hline $\mathbf{A}_{\mathbf{2}}$ & $\mathrm{L}$ & $\mathrm{VL}$ & $\mathrm{VH}$ & $\mathrm{H}$ & $\mathrm{VH}$ & $\mathrm{VL}$ & $\mathrm{H}$ & $\mathrm{L}$ & $\mathrm{M}$ & $\mathrm{VH}$ & $\mathrm{M}$ & $\mathrm{H}$ \\
\hline $\mathbf{A}_{\mathbf{3}}$ & $\mathrm{H}$ & $\mathrm{M}$ & $\mathrm{VH}$ & $\mathrm{L}$ & $\mathrm{VL}$ & $\mathrm{H}$ & $\mathrm{VL}$ & $\mathrm{M}$ & $\mathrm{VH}$ & $\mathrm{M}$ & $\mathrm{VH}$ & $\mathrm{L}$ \\
\hline $\mathbf{A}_{\mathbf{4}}$ & $\mathrm{VL}$ & $\mathrm{VH}$ & $\mathrm{M}$ & $\mathrm{VH}$ & $\mathrm{H}$ & $\mathrm{H}$ & $\mathrm{M}$ & $\mathrm{VH}$ & $\mathrm{H}$ & $\mathrm{VL}$ & $\mathrm{M}$ & $\mathrm{M}$ \\
\hline $\mathbf{A}_{\mathbf{5}}$ & $\mathrm{VH}$ & $\mathrm{H}$ & $\mathrm{VL}$ & $\mathrm{M}$ & $\mathrm{VH}$ & $\mathrm{M}$ & $\mathrm{VH}$ & $\mathrm{H}$ & $\mathrm{VL}$ & $\mathrm{VH}$ & $\mathrm{VL}$ & $\mathrm{VH}$ \\
\hline $\mathbf{A}_{\mathbf{6}}$ & $\mathrm{H}$ & $\mathrm{VL}$ & $\mathrm{H}$ & $\mathrm{VL}$ & $\mathrm{M}$ & $\mathrm{VH}$ & $\mathrm{H}$ & $\mathrm{VL}$ & $\mathrm{L}$ & $\mathrm{L}$ & $\mathrm{VL}$ & $\mathrm{H}$ \\
\hline
\end{tabular}

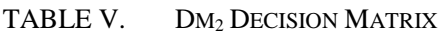

\begin{tabular}{|l|l|l|l|l|l|l|l|l|l|l|l|l|l|}
\hline $\mathbf{D M}_{\mathbf{2}}$ & $\mathbf{C}_{\mathbf{1}}$ & $\mathbf{C}_{\mathbf{2}}$ & $\mathbf{C}_{\mathbf{3}}$ & $\mathbf{C}_{\mathbf{4}}$ & $\mathbf{C}_{\mathbf{5}}$ & $\mathbf{C}_{\mathbf{6}}$ & $\mathbf{C}_{\mathbf{7}}$ & $\mathbf{C}_{\mathbf{8}}$ & $\mathbf{C}_{\mathbf{9}}$ & $\mathbf{C}_{\mathbf{1 0}}$ & $\mathbf{C}_{\mathbf{1 1}}$ & $\mathbf{C}_{\mathbf{1 2}}$ \\
\hline $\mathbf{A}_{\mathbf{1}}$ & $\mathrm{VH}$ & $\mathrm{M}$ & $\mathrm{L}$ & $\mathrm{L}$ & $\mathrm{VH}$ & $\mathrm{H}$ & $\mathrm{H}$ & $\mathrm{L}$ & $\mathrm{M}$ & $\mathrm{VH}$ & $\mathrm{H}$ \\
\hline $\mathbf{A}_{\mathbf{2}}$ & $\mathrm{H}$ & $\mathrm{VH}$ & $\mathrm{L}$ & $\mathrm{VL}$ & $\mathrm{H}$ & $\mathrm{VL}$ & $\mathrm{L}$ & $\mathrm{VH}$ & $\mathrm{VH}$ & $\mathrm{H}$ & $\mathrm{M}$ \\
\hline $\mathbf{A}_{\mathbf{3}}$ & $\mathrm{L}$ & $\mathrm{M}$ & $\mathrm{M}$ & $\mathrm{H}$ & $\mathrm{L}$ & $\mathrm{M}$ & $\mathrm{H}$ & $\mathrm{VH}$ & $\mathrm{VL}$ & $\mathrm{VL}$ & $\mathrm{VH}$ \\
\hline $\mathbf{A}_{\mathbf{4}}$ & $\mathrm{M}$ & $\mathrm{VL}$ & $\mathrm{VH}$ & $\mathrm{H}$ & $\mathrm{VH}$ & $\mathrm{VH}$ & $\mathrm{VL}$ & $\mathrm{M}$ & $\mathrm{H}$ & $\mathrm{M}$ & $\mathrm{H}$ \\
\hline $\mathbf{A}_{\mathbf{5}}$ & $\mathrm{VH}$ & $\mathrm{VH}$ & $\mathrm{H}$ & $\mathrm{M}$ & $\mathrm{M}$ & $\mathrm{H}$ & $\mathrm{VH}$ & $\mathrm{VL}$ & $\mathrm{VH}$ & $\mathrm{VH}$ & $\mathrm{VL}$ & $\mathrm{VL}$ \\
\hline $\mathbf{A}_{\mathbf{6}}$ & $\mathrm{H}$ & $\mathrm{L}$ & $\mathrm{VL}$ & $\mathrm{VH}$ & $\mathrm{VL}$ & $\mathrm{VL}$ & $\mathrm{H}$ & $\mathrm{H}$ & $\mathrm{M}$ & $\mathrm{H}$ & $\mathrm{L}$ & $\mathrm{VL}$ \\
\hline
\end{tabular}

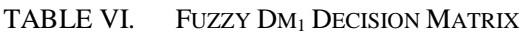

\begin{tabular}{|c|c|c|c|c|c|c|c|c|c|c|c|c|}
\hline W & E & VI & NI & E & I & NI & E & I & I & $\mathrm{E}$ & VI & $\mathrm{E}$ \\
\hline $\begin{array}{l}\text { D } \\
\mathbf{M}_{1}\end{array}$ & $\mathbf{C}_{1}$ & $\mathrm{C}_{2}$ & $\mathrm{C}_{3}$ & $\mathrm{C}_{4}$ & $\mathrm{C}_{5}$ & $\mathrm{C}_{6}$ & $\mathbf{C}_{7}$ & $\mathrm{C}_{8}$ & $\mathrm{C}_{9}$ & $\mathrm{C}_{10}$ & $\mathbf{C}_{11}$ & $\mathrm{C}_{12}$ \\
\hline $\mathbf{A}_{1}$ & $\begin{array}{l}(0.65,0.8 \\
0.95)\end{array}$ & $\begin{array}{l}(0.65,0.8 \\
0.95)\end{array}$ & )$^{(0,0.1,0.2}$ & $(0.9,1, \mathbf{1})$ & $\begin{array}{l}(0.35,0.5 \\
0.65)\end{array}$ & )$^{(0,0.1,0.2}$ & $(0.9,1,1)$ & $(0,0.1,0.2)$ & $\begin{array}{l}(0.65,0.8 \\
0.95)\end{array}$ & $\begin{array}{l}(0.35,0.5, \\
0.65)\end{array}$ & $\begin{array}{l}(0.65,0.8 \\
0.95)\end{array}$ & $(0.9,1,1)$ \\
\hline $\mathbf{A}_{2}$ & )$^{(0,0.1,0.2}$ & $(0,0,0.1)$ & $(0.9,1,1)$ & $\begin{array}{l}(0.65,0.8, \\
0.95)\end{array}$ & $(0.9,1,1)$ & $(0,0,0.1)$ & $\begin{array}{l}(0.65,0.8, \\
0.95)\end{array}$ & $(0,0.1,0.2)$ & $\begin{array}{l}(0.35,0.5 \\
0.65)\end{array}$ & $(0.9,1,1)$ & $\begin{array}{l}(0.35,0.5, \\
0.65)\end{array}$ & $\begin{array}{l}(0.65,0.8, \\
0.95)\end{array}$ \\
\hline $\mathbf{A}_{3}$ & $\begin{array}{l}(0.65,0.8 \\
0.95)\end{array}$ & $\begin{array}{l}(0.35,0.5, \\
0.65)\end{array}$ & $(0.9,1,1)$ & )$^{(0,0.1,0.2}$ & $(0,0,0.1)$ & $\begin{array}{l}(0.65,0.8, \\
0.95)\end{array}$ & $(0,0,0.1)$ & $\begin{array}{l}(0.35,0.5 \\
0.65)\end{array}$ & $(0.9,1,1)$ & $\begin{array}{l}(0.35,0.5, \\
0.65)\end{array}$ & $(0.9,1,1)$ & )$^{(0,0.1,0.2}$ \\
\hline $\mathbf{A}_{4}$ & $(0,0,0.1)$ & $(0.9,1,1)$ & $\begin{array}{l}(0.35,0.5, \\
0.65)\end{array}$ & $(0.9,1,1)$ & $\begin{array}{l}(0.65,0.8 \\
0.95)\end{array}$ & $\begin{array}{l}(0.65,0.8, \\
0.95)\end{array}$ & $\begin{array}{l}(0.35,0.5, \\
0.65)\end{array}$ & $(0.9,1,1)$ & $\begin{array}{l}(0.65,0.8 \\
0.95)\end{array}$ & $(0,0,0.1)$ & $\begin{array}{l}(0.35,0.5, \\
0.65)\end{array}$ & $\begin{array}{l}(0.35,0.5, \\
.65)\end{array}$ \\
\hline $\mathbf{A}_{5}$ & $(0.9,1,1)$ & $\begin{array}{l}(0.65,0.8, \\
0.95)\end{array}$ & $(0,0,0.1)$ & $\begin{array}{l}(0.35,0.5, \\
0.65)\end{array}$ & $(0.9,1,1)$ & $\begin{array}{l}(0.35,0.5, \\
0.65)\end{array}$ & $(0.9,1,1)$ & $\begin{array}{l}(0.65,0.8 \\
0.95)\end{array}$ & $(0,0,0.1)$ & $(0.9,1,1)$ & $(0,0,0.1)$ & $(0.9,1,1)$ \\
\hline $\mathbf{A}_{6}$ & $\begin{array}{l}(0.65,0.8, \\
0.95)\end{array}$ & $(0,0,0.1)$ & $\begin{array}{l}(0.65,0.8, \\
0.95)\end{array}$ & $(0,0,0.1)$ & $\begin{array}{l}(0.35,0.5 \\
0.65)\end{array}$ & $(0.9,1,1)$ & $\begin{array}{l}(0.65,0.8 \\
0.95)\end{array}$ & $(0,0,0.1)$ & $(0,0.1,0.2)$ & )$^{(0,0.1,0.2}$ & $(0,0,0.1)$ & $\begin{array}{l}(0.65,0.8, \\
0.95)\end{array}$ \\
\hline $\mathbf{w}$ & $\begin{array}{l}\text { (0.75,0.9, } \\
1)\end{array}$ & $\begin{array}{l}(0.55,0.7 \\
0.85)\end{array}$ & $\begin{array}{l}(0.15,0.3, \\
0.45)\end{array}$ & $\begin{array}{l}(0.75,0.9, \\
1)\end{array}$ & $\begin{array}{l}(0.35,0.55 \\
, 0.65)\end{array}$ & $\begin{array}{l}(0.15,0.3, \\
0.45)\end{array}$ & $\begin{array}{l}(0.75,0.9, \\
1)\end{array}$ & $\begin{array}{l}(0.35,0.55 \\
, 0.65)\end{array}$ & $\begin{array}{l}(0.35,0.55 \\
, 0.65)\end{array}$ & $\begin{array}{l}(0.75,0.9, \\
1)\end{array}$ & $\begin{array}{l}(0.55,0.7 \\
0.85)\end{array}$ & $\begin{array}{l}(0.75,0.9, \\
1)\end{array}$ \\
\hline
\end{tabular}


TABLE VII. FUZZY DM2 DECISION MATRIX

\begin{tabular}{|c|c|c|c|c|c|c|c|c|c|c|c|c|}
\hline W & $\mathrm{E}$ & VI & NI & E & I & NI & $\mathrm{E}$ & I & I & $\mathrm{E}$ & VI & E \\
\hline $\begin{array}{l}\text { D } \\
\mathbf{M}_{2}\end{array}$ & $\mathbf{C}_{1}$ & $\mathrm{C}_{2}$ & $\mathrm{C}_{3}$ & $\mathrm{C}_{4}$ & $\mathrm{C}_{5}$ & $\mathrm{C}_{6}$ & $\mathbf{C}_{7}$ & $\mathrm{C}_{8}$ & $\mathbf{C}_{9}$ & $\mathrm{C}_{10}$ & $\mathrm{C}_{11}$ & $\mathrm{C}_{12}$ \\
\hline $\mathbf{A}_{1}$ & $(0.9,1,1)$ & $\begin{array}{l}(0.35,0.5, \\
0.65)\end{array}$ & )$^{(0,0.1,0.2}$ & )$^{(0,0.1,0.2}$ & $(0.9,1, \mathbf{1})$ & $\begin{array}{l}(0.65,0.8, \\
0.95)\end{array}$ & $\begin{array}{l}(0.65,0.8, \\
0.95)\end{array}$ & )$^{(0,0.1,0.2}$ & $\begin{array}{l}(0.35,0.5, \\
0.65)\end{array}$ & $(0.9,1,1)$ & $\begin{array}{l}(0.65,0.8, \\
0.95)\end{array}$ & $\begin{array}{l}(0.65,0.8, \\
0.95)\end{array}$ \\
\hline $\mathbf{A}_{2}$ & $\begin{array}{l}(0.65,0.8 \\
0.95)\end{array}$ & $(0.9,1,1)$ & $\begin{array}{l}(0,0.1,0.2 \\
)^{2}\end{array}$ & $(0,0,0.1)$ & $\begin{array}{l}(0.65,0.8 \\
0.95)\end{array}$ & $(0,0,0.1)$ & $\begin{array}{l}(0,0.1,0.2 \\
)^{2}\end{array}$ & $(0.9,1,1)$ & $(0.9,1,1)$ & $\begin{array}{l}(0.65,0.8 \\
0.95)\end{array}$ & $\begin{array}{l}(0.35,0.5, \\
0.65)\end{array}$ & $\begin{array}{l}(0.35,0.5 \\
0.65)\end{array}$ \\
\hline $\mathbf{A}_{3}$ & )$^{(0,0.1,0.2}$ & $\begin{array}{l}(0.35,0.5, \\
0.65)\end{array}$ & $\begin{array}{l}(0.35,0.5, \\
0.65)\end{array}$ & $\begin{array}{l}(0.65,0.8, \\
0.95)\end{array}$ & )$^{(0,0.1,0.2}$ & $\begin{array}{l}(0.35,0.5, \\
0.65)\end{array}$ & $\begin{array}{l}(0.65,0.8, \\
0.95)\end{array}$ & $(0.9,1,1)$ & $(0,0,0.1)$ & $(0,0,0.1)$ & $(0.9,1,1)$ & $(0.9,1,1)$ \\
\hline $\mathbf{A}_{4}$ & $\begin{array}{l}(0.35,0.5 \\
0.65)\end{array}$ & $(0,0,0.1)$ & $(0.9,1,1)$ & $\begin{array}{l}(0.65,0.8, \\
0.95)\end{array}$ & $(0.9,1,1)$ & $(0.9,1,1)$ & $(0,0,0.1)$ & $\begin{array}{l}(0.35,0.5 \\
0.65)\end{array}$ & $\begin{array}{l}(0.65,0.8, \\
0.95)\end{array}$ & $\begin{array}{l}(0.35,0.5 \\
0.65)\end{array}$ & $\begin{array}{l}(0.65,0.8, \\
0.95)\end{array}$ & $\begin{array}{l}(0.35,0.5, \\
0.65)\end{array}$ \\
\hline $\mathbf{A}_{5}$ & $(0.9,1,1)$ & $(0.9,1,1)$ & $\begin{array}{l}(0.65,0.8, \\
0.95)\end{array}$ & $\begin{array}{l}(0.35,0.5, \\
0.65)\end{array}$ & $\begin{array}{l}(0.35,0.5, \\
0.65)\end{array}$ & $\begin{array}{l}(0.65,0.8, \\
0.95)\end{array}$ & $(0.9,1,1)$ & $(0,0,0.1)$ & $(0.9,1,1)$ & $(0.9,1,1)$ & $(0,0,0.1)$ & $(0,0,0.1)$ \\
\hline $\mathbf{A}_{6}$ & $\begin{array}{l}(0.65,0.8 \\
0.95)\end{array}$ & )$^{(0,0.1,0.2}$ & $(0,0,0.1)$ & $(0.9,1,1)$ & $(0,0,0.1)$ & $(0,0,0.1)$ & $\begin{array}{l}(0.65,0.8, \\
0.95)\end{array}$ & $\begin{array}{l}(0.65,0.8 \\
0.95)\end{array}$ & $\begin{array}{l}(0.35,0.5 \\
0.65)\end{array}$ & $\begin{array}{l}(0.65,0.8 \\
0.95)\end{array}$ & $\begin{array}{l}(0,0.1,0.2 \\
)\end{array}$ & $(0,0,0.1)$ \\
\hline
\end{tabular}

TABLE VIII. WEIGHTED DECISION MATRIX

\begin{tabular}{|c|c|c|c|c|c|c|c|c|c|c|c|c|}
\hline $\begin{array}{l}\text { D } \\
\mathbf{M}\end{array}$ & $\mathrm{C}_{1}$ & $\mathbf{C}_{2}$ & $\mathbf{C}_{3}$ & $\mathbf{C}_{4}$ & $\mathrm{C}_{5}$ & $\mathrm{C}_{6}$ & $\mathbf{C}_{7}$ & $\mathrm{C}_{8}$ & $\mathrm{C}_{9}$ & $\mathrm{C}_{10}$ & $\mathrm{C}_{11}$ & $\mathrm{C}_{12}$ \\
\hline $\mathbf{A}_{1}$ & $\begin{array}{l}(0.65,0.9, \\
1)\end{array}$ & $\begin{array}{l}(0.35,0.65, \\
0.95)\end{array}$ & $\begin{array}{l}(0,0.1,0 . \\
2)\end{array}$ & $(0,0.55,1)$ & $\begin{array}{l}(0.35,0 . \\
75,1)\end{array}$ & $\begin{array}{l}(0,0.45,0.9 \\
5)\end{array}$ & $\begin{array}{l}(0.65,0.9, \\
1)\end{array}$ & $\begin{array}{l}(0,0.1,0 . \\
2)\end{array}$ & $\begin{array}{l}(0.35,0.65 \\
0.95)\end{array}$ & $\begin{array}{l}(0.35,0 \\
75,1)\end{array}$ & $\begin{array}{l}(0.65,0.8,0 \\
.95)\end{array}$ & )$^{(0.65,0.9,1}$ \\
\hline $\mathbf{A}_{2}$ & $\begin{array}{l}(0,0.45,0 . \\
95)\end{array}$ & $(0,0.5,1)$ & $\begin{array}{l}(0,0.55 \\
1)\end{array}$ & $\begin{array}{l}(0,0.4,0.9 \\
5)\end{array}$ & $\begin{array}{l}(0.65,0 . \\
9,1)\end{array}$ & $(0,0,0.1)$ & $\begin{array}{l}(0,0.45,0 . \\
95)\end{array}$ & $\begin{array}{l}(0,0.55 \\
1)\end{array}$ & $\begin{array}{l}\text { (0.35,0.75, } \\
1)\end{array}$ & $\begin{array}{l}(0.65,0 . \\
9,1)\end{array}$ & $\begin{array}{l}(0.35,0.5,0 \\
.65)\end{array}$ & $\begin{array}{l}(0.35,0.65 \\
0.95)\end{array}$ \\
\hline $\mathbf{A}_{3}$ & $\begin{array}{l}(0,0.45,0 . \\
95)\end{array}$ & $\begin{array}{l}(0.35,0.5,0 \\
.65)\end{array}$ & $\begin{array}{l}(0.35,0 . \\
75,1)\end{array}$ & $\begin{array}{l}(0,0.45,0 . \\
95)\end{array}$ & $\begin{array}{l}(0,0.05, \\
0.2)\end{array}$ & $\begin{array}{l}(0.35,0.65, \\
0.95)\end{array}$ & $\begin{array}{l}(0,0.4,0.9 \\
5)\end{array}$ & $\begin{array}{l}(0.35,0 . \\
75,1)\end{array}$ & $(0,0.5,1)$ & $\begin{array}{l}(0,0.25 \\
0.65)\end{array}$ & $(0.9,1,1)$ & $(0,0.55,1)$ \\
\hline $\mathbf{A}_{4}$ & $\begin{array}{l}(0,0.25,0 . \\
65)\end{array}$ & $(0,0.5,1)$ & $\begin{array}{l}(0.35,0 . \\
75,1)\end{array}$ & $\begin{array}{l}(0.65,0.9 \\
1)\end{array}$ & $\begin{array}{l}(0.65,0 . \\
9,1)\end{array}$ & $\begin{array}{l}(0.65,0.9,1 \\
)\end{array}$ & $\begin{array}{l}(0,0.25,0 . \\
65)\end{array}$ & $\begin{array}{l}(0.35,0 \\
75,1)\end{array}$ & $\begin{array}{l}(0.65,0.8,0 \\
.95)\end{array}$ & $\begin{array}{l}(0,0.25 \\
0.65)\end{array}$ & $\begin{array}{l}(0.35,0.65 \\
0.95)\end{array}$ & $\begin{array}{l}(0.35,0.5,0 \\
.65)\end{array}$ \\
\hline $\mathbf{A}_{5}$ & $(0.9,1,1)$ & $\begin{array}{l}(0.65,0.9,1 \\
)^{2}\end{array}$ & $\begin{array}{l}(0,0.4,0 . \\
95)\end{array}$ & $\begin{array}{l}(0.35,0.5 \\
0.65)\end{array}$ & $\begin{array}{l}(0.35,0 . \\
75,1)\end{array}$ & $\begin{array}{l}(0.35,0.65, \\
0.95)\end{array}$ & $(0.9,1,1)$ & $\begin{array}{l}(0,0.4,0 . \\
95)\end{array}$ & $(0,0.5,1)$ & $(0.9,1,1)$ & $(0,0,0.1)$ & $(0,0.5,1)$ \\
\hline $\mathbf{A}_{6}$ & $\begin{array}{l}(0.65,0.8, \\
0.95)\end{array}$ & $\begin{array}{l}(0,0.05,0.2 \\
)\end{array}$ & $\begin{array}{l}(0,0.4,0 . \\
95)\end{array}$ & $(0,0.5,1)$ & $\begin{array}{l}(0,0.25, \\
0.65)\end{array}$ & $(0,0.5,1)$ & $\begin{array}{l}(0.65,0.8 \\
0.95)\end{array}$ & $\begin{array}{l}(0,0.4,0 . \\
95)\end{array}$ & $\begin{array}{l}(0,0.3,0.65 \\
)\end{array}$ & $\begin{array}{l}(0,0.45 \\
0.95)\end{array}$ & $\begin{array}{l}(0,0.05,0.2 \\
)\end{array}$ & $\begin{array}{l}(0,0.4,0.95 \\
)\end{array}$ \\
\hline
\end{tabular}


TABLE IX. NORMALIZED WeIGHTED DECISION MATRIX WITH IDEAL SOLUTIONS

\begin{tabular}{|c|c|c|c|c|c|c|c|c|c|c|c|c|}
\hline $\begin{array}{l}\text { Id } \\
\text { ea } \\
\text { l }\end{array}$ & $\mathbf{C}_{1}$ & $\mathbf{C}_{2}$ & $\mathbf{C}_{3}$ & $\mathrm{C}_{4}$ & $\mathbf{C}_{5}$ & $\mathrm{C}_{6}$ & $\mathbf{C}_{7}$ & $\mathrm{C}_{8}$ & $\mathrm{C}_{9}$ & $\mathbf{C}_{10}$ & $\mathbf{C}_{11}$ & $\mathbf{C}_{12}$ \\
\hline $\mathbf{A}_{1}$ & $\begin{array}{l}(0.4875 \\
0.81,19\end{array}$ & $\begin{array}{l}(0.1925,0 . \\
455,0.807 \\
5)\end{array}$ & $\begin{array}{l}(0,0.03,0 . \\
09)\end{array}$ & $\begin{array}{l}(0,0.495 \\
1)\end{array}$ & $\begin{array}{l}(0.1225,0 . \\
4125,0.65 \\
)\end{array}$ & $\begin{array}{l}(0,0.135,0 . \\
4275)\end{array}$ & $\begin{array}{l}(0.4875 \\
0.81,1)\end{array}$ & $\begin{array}{l}(0,0.055,0 \\
.13)\end{array}$ & $\begin{array}{l}(0.1225,0.3 \\
575,0.6175 \\
)\end{array}$ & $\begin{array}{l}(0.2625 \\
, 0.675,1 \\
)\end{array}$ & $\begin{array}{l}(0.3575,0 . \\
56,0.8075)\end{array}$ & $\begin{array}{l}(0.4875,0 \\
.81,1)\end{array}$ \\
\hline $\mathbf{A}_{2}$ & $\begin{array}{l}(0,0.405 \\
0.95)\end{array}$ & $\begin{array}{l}(0,0.35,0.8 \\
5)\end{array}$ & $\begin{array}{l}(0,0.165 \\
0.45)\end{array}$ & $\begin{array}{l}(0,0.36,0 \\
.95)\end{array}$ & $\begin{array}{l}(0.2275,0 \\
495,0.65)\end{array}$ & $\begin{array}{l}(0,0,0.045 \\
)\end{array}$ & $\begin{array}{l}(0,0.405, \\
0.95)\end{array}$ & $\begin{array}{l}(0,0.302,0 \\
.65)\end{array}$ & $\begin{array}{l}(0.1225,0.4 \\
125,0.65)\end{array}$ & $\begin{array}{l}(0.4875 \\
, 0.81,1)\end{array}$ & $\begin{array}{l}(0.1925,0 . \\
35,0.5525)\end{array}$ & $\begin{array}{l}(0.2625,0 \\
.585,0.95 \\
)\end{array}$ \\
\hline $\mathbf{A}_{3}$ & $\begin{array}{l}(0,0.405 \\
0.95)\end{array}$ & $\begin{array}{l}(0.1925,0 . \\
35,0.5525)\end{array}$ & $\begin{array}{l}(0.0525,0 \\
.225,0.45 \\
)\end{array}$ & $\begin{array}{l}(0,0.405 \\
0.95)\end{array}$ & $\begin{array}{l}(0,0.0275 \\
0.13)\end{array}$ & $\begin{array}{l}(0.0525,0 . \\
195,0.427 \\
5)\end{array}$ & $\begin{array}{l}(0,0.36,0 \\
.95)\end{array}$ & $\begin{array}{l}(0.1225,0 . \\
4125,0.65 \\
)\end{array}$ & $\begin{array}{l}(0,0.275,0 . \\
65)\end{array}$ & $\begin{array}{l}(0,0.22 \\
5,0.65)\end{array}$ & $\begin{array}{l}(0.495,0.7 \\
0.85)\end{array}$ & $\begin{array}{l}(0,0.495 \\
1)\end{array}$ \\
\hline $\mathbf{A}_{4}$ & $\begin{array}{l}(0,0.225 \\
0.65)\end{array}$ & $\begin{array}{l}(0,0.35,0.8 \\
5)\end{array}$ & $\begin{array}{l}(0.0525,0 \\
.225,0.45 \\
)\end{array}$ & $\begin{array}{l}(0.4875 \\
0.81,1)\end{array}$ & $\begin{array}{l}(0.2275,0 . \\
495,0.65)\end{array}$ & $\begin{array}{l}(0.0975,0 \\
27,0.45)\end{array}$ & $\begin{array}{l}(0,0.225, \\
0.65)\end{array}$ & $\begin{array}{l}(0.1225,0 . \\
4125,0.65 \\
)\end{array}$ & $\begin{array}{l}(0.2275,0.4 \\
4,0.6175)\end{array}$ & $\begin{array}{l}(0,0.22 \\
5,0.65)\end{array}$ & $\begin{array}{l}(0.1925,0 . \\
455,0.807 \\
5)\end{array}$ & $\begin{array}{l}(0.2625,0 \\
.45,0.65)\end{array}$ \\
\hline $\mathbf{A}_{5}$ & $\begin{array}{l}(0.675,0 . \\
9,1)\end{array}$ & $\begin{array}{l}(0.3575,0 . \\
63,0.85)\end{array}$ & $\begin{array}{l}(0,0.12,0 \\
4275)\end{array}$ & $\begin{array}{l}(0.2625 \\
0.45,0.6 \\
5)\end{array}$ & $\begin{array}{l}(0.1225,0 . \\
4125,0.65 \\
)\end{array}$ & $\begin{array}{l}(0.0525,0 . \\
195,0.427 \\
5)\end{array}$ & $\begin{array}{l}(0.675,0 . \\
9,1)\end{array}$ & $\begin{array}{l}(0,0.22,0 . \\
6175)\end{array}$ & $\begin{array}{l}(0,0.275,0 . \\
65)\end{array}$ & $\begin{array}{l}(0.675, \\
0.9,1)\end{array}$ & $\begin{array}{l}(0,0,0.085 \\
)\end{array}$ & )$^{(0,0.45,1}$ \\
\hline $\mathbf{A}_{6}$ & $\begin{array}{l}(0.4875 \\
0.72,0.9 \\
5)\end{array}$ & $\begin{array}{l}(0,0.035,0 . \\
17)\end{array}$ & $\begin{array}{l}(0,0.12,0 \\
4275)\end{array}$ & )$^{(0,0.45,1}$ & $\begin{array}{l}(0,0.1375 \\
0.4225)\end{array}$ & $\begin{array}{l}(0,0.15,0.4 \\
5)\end{array}$ & $\begin{array}{l}(0.4875 \\
0.72,0.9 \\
5)\end{array}$ & $\begin{array}{l}(0,0.22,0 \\
6175)\end{array}$ & $\begin{array}{l}(0,0.165,0 \\
4225)\end{array}$ & $\begin{array}{l}(0,0.40 \\
5,0.95)\end{array}$ & $\begin{array}{l}(0,0.035,0 . \\
17)\end{array}$ & $\begin{array}{l}(0,0.36,0 . \\
95)\end{array}$ \\
\hline$\underset{+}{\mathbf{A}}$ & $\begin{array}{l}(0.675,0 . \\
9,1)\end{array}$ & $\begin{array}{l}(0.3575,0 . \\
65,0.85)\end{array}$ & $\begin{array}{l}(0.0525,0 \\
.225,0.45 \\
)\end{array}$ & $\begin{array}{l}(0.4875 \\
0.81,1)\end{array}$ & $\begin{array}{l}(0.2275,0 . \\
495,0.65)\end{array}$ & $\begin{array}{l}(0.0525,0 \\
195,0.45)\end{array}$ & $\begin{array}{l}(0.675,0 . \\
9,1)\end{array}$ & $\begin{array}{l}(0.1225,0 . \\
4125,0.65 \\
)\end{array}$ & $\begin{array}{l}(0.1225,0.4 \\
125,0.65)\end{array}$ & $\begin{array}{l}(0.675, \\
0.9,1)\end{array}$ & $\begin{array}{l}(0.495,0.7 \\
0.85)\end{array}$ & $\begin{array}{l}(0.4875,0 \\
.81,1)\end{array}$ \\
\hline $\mathbf{A}^{-}$ & $\begin{array}{l}(0,0.225 \\
0.65)\end{array}$ & $\begin{array}{l}(0,0.035,0 . \\
17)\end{array}$ & $\begin{array}{l}(0,0.03,0 . \\
09)\end{array}$ & $\begin{array}{l}(0,0.36,0 \\
.95)\end{array}$ & $\begin{array}{l}(0,0.0275, \\
0.13)\end{array}$ & $\begin{array}{l}(0,0.135,0 . \\
4275)\end{array}$ & $\begin{array}{l}(0,0.225, \\
0.65)\end{array}$ & $\begin{array}{l}(0,0.055,0 \\
.13)\end{array}$ & $\begin{array}{l}(0,0.165,0 . \\
4225)\end{array}$ & $\begin{array}{l}(0,0.22 \\
5,0.65)\end{array}$ & $(0,00.085)$ & $\begin{array}{l}(0,0.36,0 . \\
95)\end{array}$ \\
\hline
\end{tabular}

TABLE X. NORMALIZED POSITIVE IDEAL SOLUTION MATRIX

\begin{tabular}{|c|c|c|c|c|c|c|c|c|c|c|c|c|c|}
\hline $\begin{array}{l}\text { FPI } \\
\text { S }\end{array}$ & $\mathbf{C}_{1}$ & $\mathrm{C}_{2}$ & $\mathrm{C}_{3}$ & $\mathrm{C}_{4}$ & $\mathrm{C}_{5}$ & $\mathrm{C}_{6}$ & $\mathbf{C}_{7}$ & $\mathrm{C}_{8}$ & $\mathbf{C}_{9}$ & $\mathbf{C}_{10}$ & $\mathbf{C}_{11}$ & $\mathrm{C}_{12}$ & $\mathbf{d}+\mathbf{i}$ \\
\hline $\mathbf{A}_{1}$ & $\begin{array}{l}0.14077 \\
908\end{array}$ & $\begin{array}{l}0.22114 \\
758\end{array}$ & $\begin{array}{l}0.41054 \\
080\end{array}$ & $\begin{array}{l}0.42242 \\
603\end{array}$ & $\begin{array}{l}0.10237 \\
798\end{array}$ & $\begin{array}{l}0.07088 \\
723\end{array}$ & $\begin{array}{l}0.14077 \\
908\end{array}$ & $\begin{array}{l}0.63498 \\
688\end{array}$ & $\begin{array}{l}0.06388 \\
466\end{array}$ & $\begin{array}{l}0.32763 \\
356\end{array}$ & $\begin{array}{l}0.16645 \\
820\end{array}$ & $\begin{array}{l}0.00000 \\
000\end{array}$ & $\begin{array}{l}2.70190 \\
108\end{array}$ \\
\hline $\mathbf{A}_{2}$ & $\begin{array}{l}0.34985 \\
711\end{array}$ & $\begin{array}{l}0.36414 \\
569\end{array}$ & $\begin{array}{l}0.06722 \\
165\end{array}$ & $\begin{array}{l}0.53312 \\
170\end{array}$ & $\begin{array}{l}0.00000 \\
000\end{array}$ & $\begin{array}{l}0.45052 \\
053\end{array}$ & $\begin{array}{l}0.63198 \\
101\end{array}$ & $\begin{array}{l}0.13077 \\
493\end{array}$ & $\begin{array}{l}0.00000 \\
000\end{array}$ & $\begin{array}{l}0.14077 \\
908\end{array}$ & $\begin{array}{l}0.49143 \\
497\end{array}$ & $\begin{array}{l}0.26457 \\
513\end{array}$ & $\begin{array}{l}3.42441 \\
182\end{array}$ \\
\hline $\mathbf{A}_{3}$ & $\begin{array}{l}0.63198 \\
101\end{array}$ & $\begin{array}{l}0.43310 \\
651\end{array}$ & $\begin{array}{l}0.00000 \\
000\end{array}$ & $\begin{array}{l}0.49572 \\
548\end{array}$ & $\begin{array}{l}0.71148 \\
319\end{array}$ & $\begin{array}{l}0.02250 \\
000\end{array}$ & $\begin{array}{l}0.66781 \\
360\end{array}$ & $\begin{array}{l}0.00000 \\
000\end{array}$ & $\begin{array}{l}0.15462 \\
320\end{array}$ & $\begin{array}{l}0.85440 \\
037\end{array}$ & $\begin{array}{l}0.00000 \\
000\end{array}$ & $\begin{array}{l}0.42242 \\
603\end{array}$ & $\begin{array}{l}4.39405 \\
939\end{array}$ \\
\hline $\mathbf{A}_{4}$ & $\begin{array}{l}0.85440 \\
037\end{array}$ & $\begin{array}{l}0.36414 \\
569\end{array}$ & $\begin{array}{l}0.00000 \\
000\end{array}$ & $\begin{array}{l}0.00000 \\
000\end{array}$ & $\begin{array}{l}0.00000 \\
000\end{array}$ & $\begin{array}{l}0.07937 \\
254\end{array}$ & $\begin{array}{l}0.85440 \\
037\end{array}$ & $\begin{array}{l}0.00000 \\
000\end{array}$ & $\begin{array}{l}0.07407 \\
766\end{array}$ & $\begin{array}{l}0.85440 \\
037\end{array}$ & $\begin{array}{l}0.30386 \\
400\end{array}$ & $\begin{array}{l}0.51862 \\
800\end{array}$ & $\begin{array}{l}3.90328 \\
902\end{array}$ \\
\hline $\mathbf{A}_{5}$ & $\begin{array}{l}0.00000 \\
000\end{array}$ & $\begin{array}{l}0.02000 \\
000\end{array}$ & $\begin{array}{l}0.11157 \\
957\end{array}$ & $\begin{array}{l}0.51862 \\
800\end{array}$ & $\begin{array}{l}0.10237 \\
798\end{array}$ & $\begin{array}{l}0.02250 \\
000\end{array}$ & $\begin{array}{l}0.00000 \\
000\end{array}$ & $\begin{array}{l}0.20764 \\
051\end{array}$ & $\begin{array}{l}0.15462 \\
320\end{array}$ & $\begin{array}{l}0.00000 \\
000\end{array}$ & $\begin{array}{l}1.07559 \\
286\end{array}$ & $\begin{array}{l}0.45696 \\
690\end{array}$ & $\begin{array}{l}2.66990 \\
902\end{array}$ \\
\hline $\mathbf{A}_{6}$ & $\begin{array}{l}0.21591 \\
376\end{array}$ & $\begin{array}{l}0.93980 \\
162\end{array}$ & $\begin{array}{l}0.11157 \\
957\end{array}$ & $\begin{array}{l}0.45696 \\
690\end{array}$ & $\begin{array}{l}0.44363 \\
790\end{array}$ & $\begin{array}{l}0.05425 \\
634\end{array}$ & $\begin{array}{l}0.21591 \\
376\end{array}$ & $\begin{array}{l}0.20764 \\
051\end{array}$ & $\begin{array}{l}0.34353 \\
251\end{array}$ & $\begin{array}{l}0.63198 \\
101\end{array}$ & $\begin{array}{l}0.99312 \\
638\end{array}$ & $\begin{array}{l}0.53312 \\
170\end{array}$ & $\begin{array}{l}5.14747 \\
195\end{array}$ \\
\hline
\end{tabular}


TABLE XI. NORMALIZED NEGATIVE IDEAL SOLUTION MATRIX

\begin{tabular}{|c|c|c|c|c|c|c|c|c|c|c|c|c|c|}
\hline $\begin{array}{l}\text { FI } \\
\text { NS }\end{array}$ & $\mathbf{C}_{1}$ & $\mathrm{C}_{2}$ & $C_{3}$ & $\mathrm{C}_{4}$ & $\mathrm{C}_{5}$ & $\mathrm{C}_{6}$ & $\mathbf{C}_{7}$ & $\mathrm{C}_{8}$ & $\mathrm{C}_{9}$ & $\mathbf{C}_{10}$ & $\mathrm{C}_{11}$ & $\mathrm{C}_{12}$ & $\mathbf{d}-\mathbf{i}$ \\
\hline $\mathbf{A}_{1}$ & $\begin{array}{l}0.73752 \\
5423\end{array}$ & $\begin{array}{l}0.77146 \\
5056\end{array}$ & $\begin{array}{l}0.00000 \\
0000\end{array}$ & $\begin{array}{l}0.14396 \\
1800\end{array}$ & $\begin{array}{l}0.65086 \\
6410\end{array}$ & $\begin{array}{l}0.00000 \\
0000\end{array}$ & $\begin{array}{l}0.73752 \\
5423\end{array}$ & $\begin{array}{l}0.00000 \\
0000\end{array}$ & $\begin{array}{l}0.28298 \\
9988\end{array}$ & $\begin{array}{l}0.58988 \\
8761\end{array}$ & $\begin{array}{l}0.93712 \\
7704\end{array}$ & $\begin{array}{l}0.53312 \\
1703\end{array}$ & $\begin{array}{l}5.38447 \\
2269\end{array}$ \\
\hline $\mathbf{A}_{2}$ & $\begin{array}{l}0.34985 \\
7114\end{array}$ & $\begin{array}{l}0.74941 \\
6440\end{array}$ & $\begin{array}{l}0.38448 \\
0169\end{array}$ & $\begin{array}{l}0.00000 \\
0000\end{array}$ & $\begin{array}{l}0.71148 \\
3193\end{array}$ & $\begin{array}{l}0.40562 \\
4518\end{array}$ & $\begin{array}{l}0.34985 \\
7114\end{array}$ & $\begin{array}{l}0.57589 \\
6041\end{array}$ & $\begin{array}{l}0.34353 \\
2507\end{array}$ & $\begin{array}{l}0.73752 \\
5423\end{array}$ & $\begin{array}{l}0.59448 \\
1567\end{array}$ & $\begin{array}{l}0.27128 \\
1680\end{array}$ & $\begin{array}{l}5.47343 \\
5765\end{array}$ \\
\hline $\mathbf{A}_{3}$ & $\begin{array}{l}0.34985 \\
7114\end{array}$ & $\begin{array}{l}0.07366 \\
3180\end{array}$ & $\begin{array}{l}0.41054 \\
0802\end{array}$ & $\begin{array}{l}1.03495 \\
2088\end{array}$ & $\begin{array}{l}0.00000 \\
0000\end{array}$ & $\begin{array}{l}0.06722 \\
1648\end{array}$ & $\begin{array}{l}0.32897 \\
5683\end{array}$ & $\begin{array}{l}0.63498 \\
6877\end{array}$ & $\begin{array}{l}0.25269 \\
7942\end{array}$ & $\begin{array}{l}0.00000 \\
0000\end{array}$ & $\begin{array}{l}1.07559 \\
2860\end{array}$ & $\begin{array}{l}0.14396 \\
1800\end{array}$ & $\begin{array}{l}4.37244 \\
9993\end{array}$ \\
\hline $\mathbf{A}_{4}$ & $\begin{array}{l}0.00000 \\
0000\end{array}$ & $\begin{array}{l}0.74941 \\
6440\end{array}$ & $\begin{array}{l}0.40367 \\
0638\end{array}$ & $\begin{array}{l}0.53312 \\
1703\end{array}$ & $\begin{array}{l}0.71148 \\
3193\end{array}$ & $\begin{array}{l}0.14798 \\
6486\end{array}$ & $\begin{array}{l}0.00000 \\
0000\end{array}$ & $\begin{array}{l}0.63498 \\
6877\end{array}$ & $\begin{array}{l}0.36180 \\
3929\end{array}$ & $\begin{array}{l}0.00000 \\
0000\end{array}$ & $\begin{array}{l}0.86103 \\
6197\end{array}$ & $\begin{array}{l}0.34794 \\
9350\end{array}$ & $\begin{array}{l}4.75145 \\
4812\end{array}$ \\
\hline $\mathbf{A}_{5}$ & $\begin{array}{l}0.56235 \\
2490\end{array}$ & $\begin{array}{l}0.60924 \\
8723\end{array}$ & $\begin{array}{l}0.34929 \\
3931\end{array}$ & $\begin{array}{l}0.34794 \\
9350\end{array}$ & $\begin{array}{l}0.65086 \\
6410\end{array}$ & $\begin{array}{l}0.06722 \\
1648\end{array}$ & $\begin{array}{l}0.85440 \\
0375\end{array}$ & $\begin{array}{l}0.51466 \\
6154\end{array}$ & $\begin{array}{l}0.25269 \\
7942\end{array}$ & $\begin{array}{l}0.85440 \\
0375\end{array}$ & $\begin{array}{l}0.00000 \\
0000\end{array}$ & $\begin{array}{l}0.10295 \\
6301\end{array}$ & $\begin{array}{l}5.16605 \\
3698\end{array}$ \\
\hline $\mathbf{A}_{6}$ & $\begin{array}{l}0.64361 \\
7705\end{array}$ & $\begin{array}{l}0.00000 \\
0000\end{array}$ & $\begin{array}{l}0.34929 \\
3931\end{array}$ & $\begin{array}{l}0.10295 \\
6301\end{array}$ & $\begin{array}{l}0.31250 \\
0000\end{array}$ & $\begin{array}{l}0.02704 \\
1635\end{array}$ & $\begin{array}{l}0.64361 \\
7705\end{array}$ & $\begin{array}{l}0.51466 \\
6154\end{array}$ & $\begin{array}{l}0.00000 \\
0000\end{array}$ & $\begin{array}{l}0.34985 \\
7114\end{array}$ & $\begin{array}{l}0.09192 \\
3882\end{array}$ & $\begin{array}{l}0.00000 \\
0000\end{array}$ & $\begin{array}{l}3.03547 \\
4426\end{array}$ \\
\hline
\end{tabular}

TABLE XII. FINAL RANKING OF ALTERNATIVES

\begin{tabular}{|c|c|c|c|c|c|}
\hline Rank & d-i & $\mathbf{d}+\mathbf{i}$ & D+i+D-i & Cei & Rank \\
\hline yHomework Math Solver $\left(A_{1}\right)$ & 2.701901083 & 5.384472269 & 8.086373351 & 0.334130143 & 6 \\
\hline $\operatorname{Cymath}\left(\mathbf{A}_{2}\right)$ & 3.42441182 & 5.473435765 & 8.897847585 & 0.384858449 & 4 \\
\hline Malmath $\left(\mathbf{A}_{3}\right)$ & 4.394059393 & 4.372449993 & 8.766509386 & 0.501232497 & 2 \\
\hline Math 42( $\left.\mathrm{A}_{4}\right)$ & 3.903289017 & 4.751454812 & 8.654743829 & 0.450999948 & 3 \\
\hline $\operatorname{MathPapa}\left(\mathbf{A}_{5}\right)$ & 2.669909017 & 5.166053698 & 7.835962715 & 0.340725079 & 5 \\
\hline $\operatorname{PhotoMath}\left(\mathbf{A}_{6}\right)$ & 5.147471948 & 3.035474426 & 8.182946373 & 0.629048721 & 1 \\
\hline
\end{tabular}

\section{CONCLUSION}

The user ratings of mobile applications found at the app stores can sometimes be not sufficient for revealing the essential quality of the mobile applications. Therefore precise and easy techniques are desired. By developing a multi criteria decision making evaluation to rank mobile mathematics learning applications, this study intends to enhance the use and effectiveness of mobile Mathematics learning applications thereby improving the quality of learning across all learning platforms. In addition, the study also helps in setting standards in relation to ISO practices upon which the quality and usability of MMLAs can be determined. It also contributes to the research of mobile applications through the use of fuzzy TOPSIS.

\section{FUTURE WORK}

Tends to focus towards increasing the number of decision makers, alternatives as well as comparing and contrasting the efficiency of different MCDM methods applied to improve the precision of the selection process. It is recommended that user friendly interface or software could be initiated for the service of decision makers.

\section{REFERENCES}

[1] S. Başaran, "Multi-Criteria Decision Analysis Approaches for Selecting and Evaluating Digital Learning Objects," Procedia Computer Science, vol. 102, pp. 251-258, 2016. DOI: https://doi.org/10.1016/j.procs.2016.09.398.
[2] M. L. Crescente and D. Lee, "Critical issues of m-learning: design models, adoption processes, and future trends," Journal of the Chinese Institute of Industrial Engineers, vol. 28, no. 2, pp. 111-123, Mar. 2011.

[3] A. Drigas and M. Pappas, "A Review of Mobile Learning Applications for Mathematics," International Journal of Interactive Mobile Technologies (iJIM), vol. 9, no. 3, p. 18, Jul. 2015.

[4] R. Pierce, K. Stacey, and A. Barkatsas, "A scale for monitoring students' attitudes to learning mathematics with technology," Computers \& Education, vol. 48, no. 2, pp. 285-300, Feb. 2007.

[5] M., Bjerede, K. Atkins, and C., Dede, "A Special Report: Ubiquitous Mobile Technologies and the Transformation of Schooling," Educational Technology, pp.3-7,2010.

[6] S. Başaran and Y. Haruna, "Integrating FAHP and TOPSIS to evaluate mobile learning applications for mathematics," Procedia Computer Science, vol. 120, pp. 91-98, 2017. DOI: https://doi.org/10.1016/j.procs.2017.11.214.

[7] R. H. Kay and L. Knaack, "Evaluating the learning in learning objects," Open Learning: The Journal of Open, Distance and e-Learning, vol. 22, no. 1, pp. 5-28, Feb. 2007.

[8] G. Büyüközkan and S. Güleryüz, "Multi Criteria Group Decision Making Approach for Smart Phone Selection Using Intuitionistic Fuzzy TOPSIS," International Journal of Computational Intelligence Systems, vol. 9, no. 4, p. 709, 2016.

[9] R. Trestian, A.-N. Moldovan, C. H. Muntean, O. Ormond, and G.-M. Muntean, "Quality Utility modelling for multimedia applications for Android Mobile devices," IEEE international Symposium on Broadband Multimedia Systems and Broadcasting, pp. 1-6, Jun. 2012.

[10] T.L., Leacock, and J.C., Nesbit,. "A framework for evaluating the quality of multimedia learning resources," Journal of Educational Technology \& Society, 10(2), pp.44-59,2007.

[11] S. Basaran and O. J., Aduradola, "A Multi-Criteria Decision Making to Rank Android based Mobile Applications for Mathematics," 
International Journal of Advanced Computer Science and Applications, vol. 9, no. 7, 2018. DOI: 10.14569/IJACSA.2018.090714.

[12] E. K. Zavadskas, Z. Turskis, and S. Kildienè, "State Of Art Surveys Of Overviews On Mcdm/Madm Methods," Technological and Economic Development of Economy, vol. 20, no. 1, pp. 165-179, Mar. 2014.

[13] A. Daghouri, K. Mansouri, and M. Qbadou, "Multi Criteria Decision Making methods for Information System Selection: A Comparative Study," 2018 International Conference on Electronics, Control, Optimization and Computer Science (ICECOCS), Dec. 2018.

[14] I. B. Huang, J. Keisler, and I. Linkov, "Multi-criteria decision analysis in environmental sciences: Ten years of applications and trends," Science of The Total Environment, vol. 409, no. 19, pp. 3578-3594, Sep. 2011.

[15] S. Rouhani, M. Ghazanfari, and M. Jafari, "Evaluation model of business intelligence for enterprise systems using fuzzy TOPSIS," Expert Systems with Applications, vol. 39, no. 3, pp. 3764-3771, Feb. 2012.

[16] R.M., Palloff, K. Pratt, and D., Stockley, "Building learning communities in cyberspace: Effective strategies for the online classroom," The Canadian Journal of Higher Education, 31(3), p.175178,2001 .

[17] M. Virvou and E. Alepis, "Mobile educational features in authoring tools for personalised tutoring," Computers \& Education, vol. 44, no. 1, pp. 53-68, Jan. 2005.

[18] L. F. Motiwalla, "Mobile learning: A framework and evaluation," Computers \& Education, vol. 49, no. 3, pp. 581-596, Nov. 2007.

[19] F., Lehner, \& H., Nosekabel, "The role of mobile devices in E-Learning first experiences with a wireless E-Learning environment," IEEE International Workshop on Wireless and Mobile Technologies in Education, pp. 103-106, IEEE, 2002.

[20] H. U., Hoppe, S., Eimler, \& L., Bollen, "The use of mobile computing to support SMS dialogues and classroom discussions in a literature course," IEEE International Conference on Advanced Learning Technologies, pp. 550-554, IEEE, 2004.

[21] M., Skillen, "Mobile Learning: Impacts on Mathematics Education.," the 20th Asian Technology Conference in Mathematics, pp. 205-214, China., 2015.

[22] G. Botzer, and M., Yerushalmy, "Mobile application for mobile learning," In Proceedings of IADIS International Conference on Cognition and Exploratory Learning in Digital Age (CELDA 2007), pp. 7-9, December 2007.

[23] N., Roberts, G., Spencer-Smith, R. Vanska, and S., Eskelinen, "From challenging assumptions to measuring effect: Researching the Nokia mobile mathematics service in South Africa," South African Journal of Education, vol. 35, no. 2, pp.1045-1045, 2015.
[24] C. Hoyles and J.-B. Lagrange, Eds., "Mathematics Education and Technology-Rethinking the Terrain," New ICMI Study Series, 2010.

[25] K., Melhuish and G., Falloon, "Looking to the future: M-learning with the iPad," Computers in New Zealand Schools: Learning, Leading, Technology, vol. 22, no.3, pp. 1-16, 2010.

[26] P., Drijvers, "Digital technology in mathematics education: Why it works (or doesn't)." In Selected regular lectures from the 12th international congress on mathematical education, pp. 135-151. Springer, Cham, 2015.

[27] M. Z. Naghadehi, R. Mikaeil, and M. Ataei, "The application of fuzzy analytic hierarchy process (FAHP) approach to selection of optimum underground mining method for Jajarm Bauxite Mine, Iran," Expert Systems with Applications, vol. 36, no. 4, pp. 8218-8226, May 2009.

[28] M. Vafaeipour, S. Hashemkhani Zolfani, M. H. Morshed Varzandeh, A. Derakhti, and M. Keshavarz Eshkalag, "Assessment of regions priority for implementation of solar projects in Iran: New application of a hybrid multi-criteria decision making approach," Energy Conversion and Management, vol. 86, pp. 653-663, Oct. 2014.

[29] S. Ballı and S. Korukoğlu, "Operating System Selection Using Fuzzy AHP and TOPSIS Methods," Mathematical and Computational Applications, vol. 14, no. 2, pp. 119-130, Aug. 2009.

[30] S. Rouhani, M. Ghazanfari, and M. Jafari, "Evaluation model of business intelligence for enterprise systems using fuzzy TOPSIS," Expert Systems with Applications, vol. 39, no. 3, pp. 3764-3771, Feb. 2012.

[31] F. Torfi, R. Z. Farahani, and S. Rezapour, "Fuzzy AHP to determine the relative weights of evaluation criteria and Fuzzy TOPSIS to rank the alternatives," Applied Soft Computing, vol. 10, no. 2, pp. 520-528, Mar. 2010.

[32] A. A. Economides, "Requirements of Mobile Learning Applications," International Journal of Innovation and Learning, vol. 5, no. 5, p. 457, 2008.

[33] K. Singh, N. Naicker and M. Rajkoomar. Selection of Learning Apps to Promote Critical Thinking in Programming Students using Fuzzy TOPSIS. International Journal of Advanced Computer Science and Applications, Vol. 12, no.10, 2021 10.14569/IJACSA.2021.0121042

[34] N. K. Ibrahim et al., "Multi-Criteria Evaluation and Benchmarking for Young Learners' English Language Mobile Applications in Terms of LSRW Skills," IEEE Access, vol. 7, pp. 146620-146651, 2019. DOI: 10.1109/ACCESS.2019.2941640.

[35] Chunhe Zhao, Balaanand Muthu, and P. Mohamed Shakeel,"MultiObjective Heuristic Decision Making and Benchmarking for Mobile Applications in English Language Learning," ACM Transactions on Asian and Low-Resource Language Information Processing. vol. 20, no. 5, pp. 1-16, 2021. DOI:https://doi.org/10.1145/3439799. 